\title{
The giant devil ray Mobula mobular (Bonnaterre, 1788) is not giant, but it is the only spinetail devil ray
}

\author{
Giuseppe Notarbartolo di Sciara ${ }^{1 *}$, Guy Stevens ${ }^{2}$ and Daniel Fernando $2,3,4$
}

\begin{abstract}
Mobula mobular, a mobulid species once considered a Mediterranean Sea endemic, has received its common name "giant devil ray" based on repeated misidentifications of oceanic manta rays, Mobula birostris, that had strayed into the Mediterranean, where they had never been reported from before. Based on the maximum known size $(350 \mathrm{~cm}$ disc width) of M. mobular, when compared to some of its congenerics, the giant devil ray is not giant at all. A recent revision of the phylogeny and taxonomy of genus Mobula, which included, amongst other things, the decision to consider the circumtropical spinetail devil ray M. japanica a junior synonym of M. mobular, has caused the latter species to become circumglobal, and the only known mobulid with a tail spine. As a consequence, it is here recommended that the common name of M. mobular be "spinetail devil ray".
\end{abstract}

Keywords: Mobulids, Manta, Fish nomenclature, Taxonomic misidentification

\section{Background}

Understanding the correct taxonomy of manta and devil rays (Mobula spp.) has remained challenging since the initial description of the first two species within the monotypic family Mobulidae in the late eighteenth century (Bonnaterre, 1788; Walbaum, 1792). Nomenclatural confusion has persisted for centuries, exacerbated by inadequate reports and identifications of mobulid species across the world's oceans (Notarbartolo di Sciara, 1987). As a consequence, many descriptions were not placed into a wider taxonomic context, preventing the accurate determination of the range extent of the different species, and resulting in the attribution of a plethora of different names to the same species (Notarbartolo di Sciara, 1987). Confounding this issue for mobulids is: a) the subtle morphological differences amongst species of Mobula, b) the poor representation of mobulid specimens in museum collections, often due to their large size, and c) limitations to the heuristic process intrinsic to pre-digital zoological investigations. As

\footnotetext{
*Correspondence: disciara@tethys.org

${ }^{1}$ Tethys Research Institute, Viale G.B. Gadio 2, 20121 Milan, Italy

Full list of author information is available at the end of the article
}

for all early taxonomic endeavours, the learning process was hindered by a lack of supporting genetic insight, by the unavailability of photographic documentation, and by slow and intermittent communications, which caused most ichthyologists to work in isolation.

Conditions have dramatically improved in recent decades as a result of significant scientific and technological advances that combine to enable precise and unambiguous morphological documentations. The scientific advancement of genomic investigations has also led to the streamlining of taxonomy with phylogenetics, often re-shaping our assessments of species classifications as a result (Wiley \& Lieberman, 2011). Finally, the immersion of investigators in a collective medium, facilitated by the Internet, has also allowed unprecedented opportunities for comparisons, communication, and collaboration. As a consequence, our understanding of the taxonomic status of mobulids has improved considerably in the past decade, with the reorganisation of the family into a configuration reflecting our increasing understanding of the species' phylogenies (Adnet et al., 2012; Poortvliet et al., 2015; White et al., 2017; Hosegood et al., 2018).

(c) The Author(s). 2020 Open Access This article is licensed under a Creative Commons Attribution 4.0 International License, which permits use, sharing, adaptation, distribution and reproduction in any medium or format, as long as you give appropriate credit to the original author(s) and the source, provide a link to the Creative Commons licence, and indicate if changes were made. The images or other third party material in this article are included in the article's Creative Commons licence, unless indicated otherwise in a credit line to the material. If material is not included in the article's Creative Commons licence and your intended use is not permitted by statutory regulation or exceeds the permitted use, you will need to obtain permission directly from the copyright holder. To view a copy of this licence, visit http://creativecommons.org/licenses/by/4.0/. 
The ramifications of the original taxonomic confusion affecting this ray family continue to persist. Therefore, clarity is required if the correct research conclusions and effective conservation efforts are to be achieved. Until recently, one such area of confusion surrounded the giant devil ray, Mobula mobular (Bonnaterre, 1788), a Mediterranean species, and the circumtropical spinetail devil ray, Mobula japanica (Müller \& Henle, 1841). Many morphological traits shared by $M$. mobular and $M$. japanica (such as colour, shape of teeth, position of spiracles, presence of a tail spine, and tail length) set these species apart from other Mobula (Notarbartolo di Sciara, 1987). Until the revision by White et al. (2017), M. mobular was considered to be distinct from $M$. japanica largely due to the purported significantly larger size of the former, said to reach a disc width (DW) in excess of $5 \mathrm{~m}$ (Bigelow \& Schroeder, 1953). In addition, evidence of minor morphological and morphometric differences was recognised between the two (Notarbartolo di Sciara, 1987). On such bases, recommendations were made to keep the two taxa provisionally separate, pending further investigations (Notarbartolo di Sciara, 1987; Adnet et al., 2012; Poortvliet et al., 2015). As a consequence of such uncertainties, the difficulty of distinguishing M. mobular from $M$. japanica also resulted in confusion about their respective ranges, with the former having been frequently reported outside of the Mediterranean Sea in various North Atlantic locations; such as Ireland, Portugal, Madeira, the Canary islands, West Africa (from Morocco to Senegal), and even Cuba (Notarbartolo di Sciara, 1987). Conversely, $M$. japanica was reported in the Mediterranean (Rafrafi-Nouira et al., 2015; Capapé et al., 2015; Sakalli et al., 2016). For this reason, several authors recommended that the determination of the ranges of these two nominal species be placed on hold pending a clarification of their taxonomical relationship (Notarbartolo di Sciara, 1987; Notarbartolo di Sciara et al., 2015; Abudaya et al., 2017).

Recently, the contribution by molecular methods to taxonomic investigations have provided strong evidence in support of the two taxa being a single species (Poortvliet et al., 2015; White et al., 2017; Hosegood et al., 2018). This caused $M$. japanica to become a junior synonym of $M$. mobular, the latter resulting in a circumglobal species. However, this new configuration still leaves unresolved the matters of the size and morphological differences between the two formerly recognised taxa. Here, we intend to address these matters and assess their substantiation; with the intent of disputing the widely reported notion that $M$. mobular is a giant of its kind, and asserting that it is the only spinetail devil ray.

\section{Sizeable mistakes}

The type description of Raja mobular (= Mobula mobular) by P. J. Bonnaterre in 1788 is based on an earlier description by H.L. Duhamel du Monceau (1782), who reported on a specimen captured in a fixed tuna trap near Marseille (France) in 1723, with a DW just under $5 \mathrm{~m}(\sim$ $6 \mathrm{ft}$. for each "wing", and $3 \mathrm{ft}$. 10 in for the trunk between).

Two additional reports also purported the notion that M. mobular attains a gigantic size. The first of these is a communication by Pellegrin (1901), reporting on the capture near Oran (Algeria) of a huge ray, "appartenant très probablement à l'espèce méditerranéenne Dicerobatis giorna" (= M. mobular), having a DW of $5.2 \mathrm{~m}$ and a weight of $900 \mathrm{~kg}$, but with no further details offered. Pellegrin (1901) also mentioned the capture in 1898 of another ray, about $5 \mathrm{~m}$ wide ("mesurant monté 5 mètres environ") in the Bay of Rosas on the Mediterranean coast of Spain, acquired by the National Museum of Paris. The presence of this stuffed specimen (MNHN 1899-1) in the Paris Museum, labelled as M. mobular, was confirmed in 1987 by B. Seret (in litteris) to be a female Mobula birostris (Bancroft, 1829) with a DW of approximately $470 \mathrm{~cm}$.

A fourth instance of a very large mobulid from the region involved a ray captured in September 1916 in the Gulf of Cadiz (Spain), just outside of the Mediterranean Sea. That specimen, with a DW of $4.55 \mathrm{~m}$ and a weight of $358 \mathrm{~kg}$, was identified as M. mobular by Lozano Rey (1928). However, based on Lozano Rey's description and published photograph (Fig. 1), it can be concluded that this Cadiz specimen was in fact $M$. birostris for the following reasons. First, the reported mouth width ("90 $\mathrm{cm}$ de anchura de boca"), equalling $19.8 \%$ of the ray's DW, is much larger than the mouth width of $M$. mobular, reported as $11.9 \%$ DW (coefficient of variation based on samples of $M$. mobular and M. japanica $=3.9$ ) by Notarbartolo di Sciara (1987), but is consistent with the metric for M. birostris (Marshall et al., 2009). Second, the distinctive dorsal white shoulder markings clearly visible in the photograph in Lozano Rey's report are typical of $M$. birostris (Fig. 1a-b) (Stevens et al., 2018), yet quite different from the thick dark band which stretches from eye-toeye on the nuchal region of M. mobular (Fig. 1c) (Stevens et al., 2018). Third, the length of the unfurled cephalic fins of the Cadiz specimen is consistent with that of $M$. birostris (Fig. 1a-b). Finally, the eyes of this specimen protrude from the contours of the animal's head, like in $M$. birostris (Fig. 1a-b), in contrast to M. mobular (Fig. 1c).

The sizes of the four specimens mentioned above all greatly exceed the maximum size of $M$. mobular reported in recent decades from a variety of sources across multiple localities. For example, in a sample of 274M. mobular of both sexes, many of which were sexually mature, captured off Gaza (Palestine) between 2014 and 2016, the maximum recorded DW was $320 \mathrm{~cm}$ (mean $=273 \mathrm{~cm}$, range 173-320 $\mathrm{cm}$ ) (Abudaya et al., 2017). Reliable measurements of specimens of $M$. mobular captured in the Mediterranean Sea over the past few decades (e.g., Notarbartolo di Sciara and 


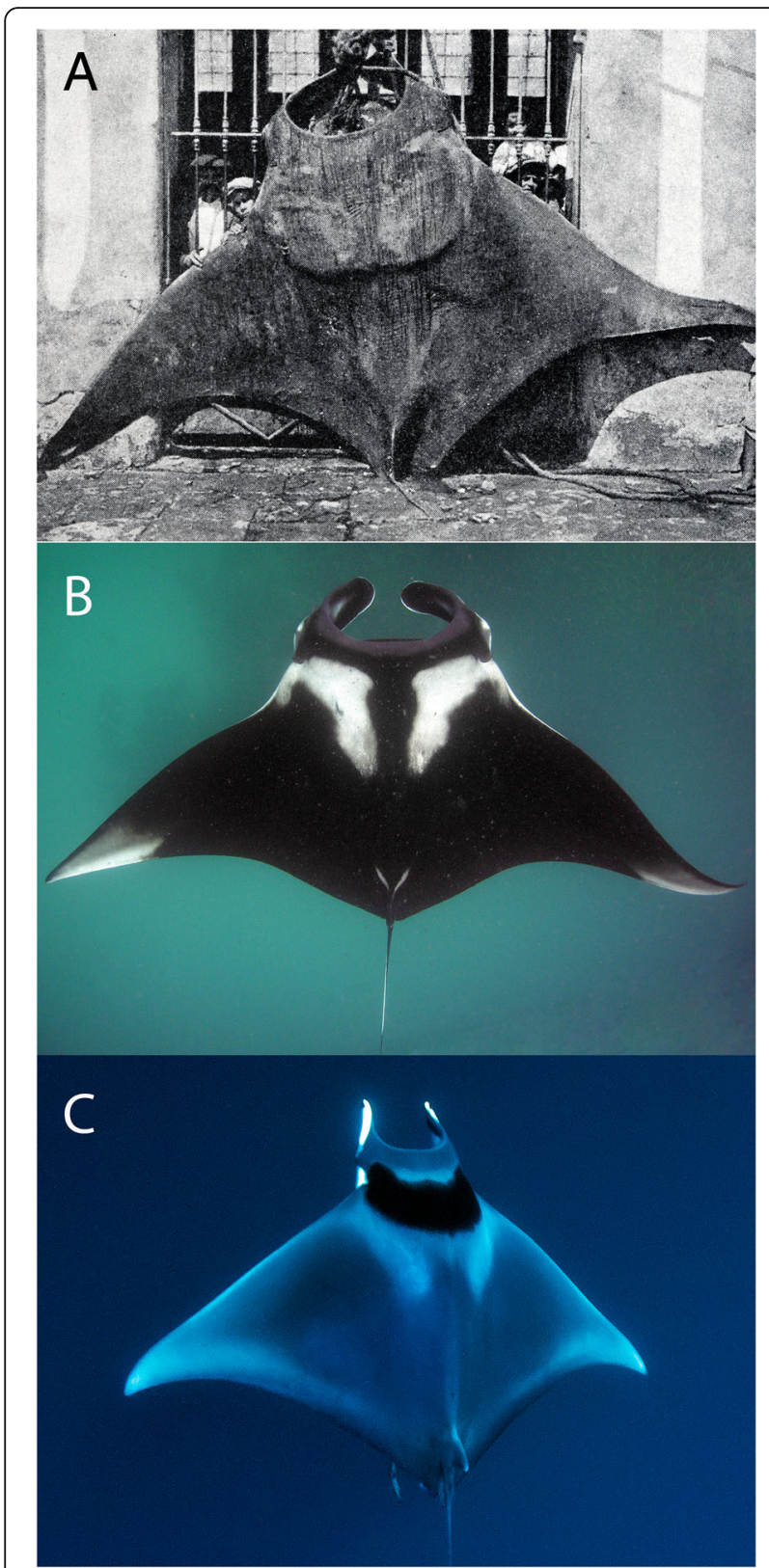

Fig. 1 a A specimen of Mobula birostris measuring $455 \mathrm{~cm}$ DW, landed in Cadiz, Spain in 1916, and identified as Mobula mobular (Lozano Rey 1928). Reprinted with permission from the Museo Nacional de Ciencias Naturales, Madrid. b M. birostris from the Maldives ( $\odot$ Guy Stevens, The Manta Trust). c M. mobular from California, US (๑ Mike Couffer)

Serena, 1988 ; Bradai \& Capapé, 2001; Hemida et al., 2002; Celona, 2004; Scacco et al., 2008; Bello et al., 2012; Holcer et al., 2012) never provided DW sizes exceeding $350 \mathrm{~cm}$; the latter having been reported by Storai et al. (2011) from a tuna trap in southwestern Sardinia. The measured sizes of $M$. mobular from the Mediterranean Sea are, in fact, consistent with the maximum reported size of $310 \mathrm{~cm} \mathrm{DW}$ for $M$. japanica (= M. mobular) in New Zealand (Paulin et al., 1982). Notarbartolo di Sciara (1987) noted that the maximum size in this species may vary between populations. Indeed, in a sample of 78 specimens from the Gulf of California, many of which were sexually mature, no individual reached a DW of $240 \mathrm{~cm}$ (Notarbartolo di Sciara, 1988).

Given that no accurately measured $M$. mobular has ever exceeded a DW of $350 \mathrm{~cm}$, combined with the aforementioned misidentification ascertained through the photograph published by Lozano (1928), it can be presumed that the specimens mentioned by Duhamel du Monceau (1782) and Pellegrin (1901), having DWs of 483 and $520 \mathrm{~cm}$, were not M. mobular, but instead $M$. birostris (Table 1).

\section{Morphological, morphometric and genomic aspects}

Most diagnostic characteristics of $M$. mobular fully coincide with those formerly delineated for $M$. japanica, and in their combination set it apart from other Mobula species. These characteristics include: colouration, peg-like teeth, the longest tail of all Mobula (with a series of denticles running longitudinally on both sides), slit-like spiracles situated dorsally to the plane of the pectoral fins, a spine at the base of the tail, and the morphology of the branchial filter plates (Notarbartolo di Sciara, 1987; Stevens et al., 2018). However, some morphological, morphometric and genetic differences between the two taxa exist. Adnet et al. (2012) argued for the validity of the species' separation on the basis of tooth morphology, although they admitted that dental differences are tenuous. Proportional dimensions indicate the absence of major differences between the two taxa, except DW, which is $10-14 \%$ greater in Mediterranean Sea specimens (see Additional File 1 for details), conferring to rays from this region a broader appearance. Finally, Bustamante et al. (2015), comparing the two taxa's mitogenomes, suggested the existence of a sister-cryptic species complex with very limited divergence (>99.9\% genetic identity), which could be explained as the result of a geographically and numerically restricted population of M. mobular within the Mediterranean Sea. Indeed, the presence of population structuring within this circumglobal species, with minor differentiation between the Indian/Pacific and Atlantic/Mediterranean geographical populations (Hosegood et al., 2018), can be ultimately reflected into the observed phenotypic differences, and should not be surprising.

\section{Conclusions}

Having ascertained that two of the gigantic mobulids misidentified as M. mobular (the Rosas and the Cadiz specimens) were oceanic manta rays $M$. birostris, we propose that the Marseille and Oran rays were also $M$. 
Table 1 Large specimens, presumed or confirmed as Mobula birostris, originally identified as M. mobular between 1723 and 1916 (see text for references)

\begin{tabular}{lllll}
\hline Originally identified & DW $(\mathrm{cm})$ & Location & Year & Presumed (P) / Confirmed (C) \\
\hline Mobula mobular & 483 & Marseilles, France & 1723 & Mobula birostris (P) \\
Mobula mobular & 470 & Bay of Rosas, Spain & 1898 & Mobula birostris (C) \\
Mobula mobular & 520 & Oran, Algeria & 1901 & Mobula birostris (P) \\
Mobula mobular & 455 & Cadiz, Spain & 1916 & Mobula birostris (C) \\
\hline
\end{tabular}

DW Disc Width

birostris that had strayed into the Mediterranean Sea. Other records exist of $M$. birostris straying north of its normal range in the Atlantic, including off New England (U.S.), Georges Bank (U.S./Canada), and Madeira and the Azores (Portugal) (Bigelow \& Schroeder, 1953; Sobral \& Alfonso, 2014). The occurrence of M. birostris within the Mediterranean Sea has never previously been recorded. Therefore, the specimen captured off Rosas and conserved in the Paris Museum Is the first confirmed record of this species in the region.

Our suggestion, that the specimen on which Bonnaterre (1788) based the type description of Mobula mobular was presumably a $M$. birostris, raises a taxonomic complication that we do not wish to pursue for the sake of nomenclatural stability. The level of uncertainty contained in ancient, second-hand reports involving measurements of such large specimens should also be considered.

Based on all currently available sources, we recommend that the maximum size of $M$. mobular reported in the literature be scaled down to $350 \mathrm{~cm}$ DW. We also consider that the species' common name of "giant devil ray" is no longer justifiable when placed into perspective with the much larger maximum sizes of its congenerics, the oceanic manta ray $M$. birostris $(680 \mathrm{~cm} \mathrm{DW})$ and of the reef manta ray $M$. alfredi $(450 \mathrm{~cm} \mathrm{DW})$, and with the comparable maximum size of the sicklefin devil ray $M$. tarapacana (340 cm DW) (Stevens et al., 2018). Furthermore, with the disappearance of the spinetail devil ray $M$. japanica from the roster of valid mobulid species (White et al., 2017), and with the tail spine being the most obvious and unique diagnostic feature of this species, we find it more sensible to propose that $M$. mobular inherit the common name of $M$. japanica, and henceforth be called the "spinetail devil ray" (Stevens et al., 2018), rather than extending the groundless name "giant devil ray" to all specimens formerly known as $M$. japanica.

\section{Supplementary information}

Supplementary information accompanies this paper at https://doi.org/10. 1186/s41200-020-00187-0.

Additional file 1 Measurements of Mobula mobular. Description of data: The file contains measurements of four specimens of M. mobular, and basic statistics of the sample are compared with statistics derived from the same measurements in a sample of 19 M. japanica (= M. mobular)

from the Gulf of California, Mexico (Notarbartolo di Sciara, 1988).

\section{Acknowledgements}

Not applicable.

Authors' contributions

GNdS, GS and DF all contributed to the writing of this article. The authors read and approved the final manuscript.

Funding

Not applicable.

Availability of data and materials

Please see Additional File 1.

Ethics approval and consent to participate

Not applicable.

Consent for publication

Not applicable.

\section{Competing interests}

The authors declare that they have no competing interests.

\section{Author details}

${ }^{1}$ Tethys Research Institute, Viale G.B. Gadio 2, 20121 Milan, Italy. ${ }^{2}$ The Manta Trust, Catemwood House, Norwood Lane, Corscombe, Dorset DT2 ONT, UK. ${ }^{3}$ Department of Biology and Environmental Science, Linnaeus University, 39182 Kalmar, Sweden. ${ }^{4}$ Blue Resources Trust, Colombo, Sri Lanka.

Received: 11 June 2019 Accepted: 16 April 2020

Published online: 30 April 2020

\section{References}

Abudaya M, Ulman A, Salah J, Fernando D, Wor C, Notarbartolo di Sciara G. Speak of the devil ray (Mobula mobular) fishery in Gaza. Rev Fish Biol Fisheries. 2017. https://doi.org/10.1007/s11160-017-9491-0.

Adnet S, Cappetta H, Guinot G, Notarbartolo di Sciara G. Evolutionary history of the devilrays (Chondrichthyes: Myliobatiformes) from fossil and morphological inference. Zool J Linnean Soc. 2012;166:132-59. https://doi. org/10.1111/j.1096-3642.2012.00844.x.

Bancroft EN. On the fish known in Jamaica as the sea devil (Chephalopholis manta). Zool J. 1829:4:444-57.

Bello G, Lipej L, Dulcic J. Comments on a finding of Mobula mobular (Mobulidae) in the Adriatic Sea. Cybium. 2012;36(4):575-7.

Bigelow HB, Schroeder WC. Fishes of the Western North Atlantic. Part Two. In: Sawfishes, Guitarfishes, Skates and Rays. New Haven: Chimaeroids, Memoir, Sears Foundation for Marine Research, Number l; 1953.

Bonnaterre PJ. Tableau Encyclopédique et Méthodique des Trois Règnes de la Nature, Ichtyologie. In: A Paris, chez Panckoucke, Libraire, Hôtel de Thou, rue des Poitevins. Avec l'approbation et privilège du Roi; 1788.

Bradai MN, Capapé C. Captures du diable de mer, Mobula mobular, dans le Golfe de Gabès (Tunisie Méridionale, Méditerranée Centrale). Cybium. 2001;25(4): 389-91.

Bustamante C, Barría C, Vargas-Caro C, Ovenden JR, Bennett MB. The phylogenetic position of the giant devil ray Mobula mobular (Bonnaterre, 
1788) (Myliobatiformes, Myliobatidae) inferred from the mitochondrial genome. Mitochondrial DNA. 2015. https://doi.org/10.3109/19401736.2015. 1074208.

Capapé C, Rafrafi-Nouira S, El Kamel-Moutalibi O, Boumaiza M, Reynaud C. First Mediterranean records of spinetail devil ray Mobula japanica (Elasmobranchii: Raijformes: Mobulidae). Acta Ichthyol Piscat. 2015;45(2):211-5. https://doi.org/ 10.3750/AIP2015.45.2.13

Celona A. Catture ed avvistamenti di mobula, Mobula mobular (Bonnaterre, 1788) nelle acque dello Stretto di Messina. Annales. 2004;14:11-8.

Duhamel du Monceau HL. Traité général des pêches et histoire des poissons ou des animaux qui vivent dans l'eau, vol. 2. Paris: Saillant \& Nyon; 1782. p. 9

Hemida F, Mehezem S, Capapé C. Captures of the giant devil ray, Mobula mobular Bonnaterre, 1788 (Chondrichthyes: Mobulidae) off the Algerian coast (southern Mediterranean). Acta Adriat. 2002;43(2):69-76.

Holcer D, Lazar B, Mackelworth P, Fortuna CM. Rare or just unknown? The occurrence of the giant devil ray (Mobula mobular) in the Adriatic Sea. J Appl Ichthyol. 2012;29(1):134-44. https://doi.org/10.1111/jai.12034.

Hosegood J, Humble E, Ogden R, de Bruyn M, Creer S, Stevens G, Abudaya M, Bassos-Hull K, Bonfil R, Fernando D, Foote AD, Hipperson H, Jabado RW, Kaden J, Moazzam M, Peel L, Pollett S, Ponzo A, Poortvliet M, Salah J, Senn H, Stewart J, Wintner S, Carvalho G. Phylogenomic and species delimitation of mobulid rays reveals cryptic diversity and a new species of manta ray. bioRxiv. 2018. https://doi.org/10.1101/458141.

Lozano Rey L. Fauna Iberica. In: Peces. Tomo primero. Madrid (Hipodromo): Museo Nacional de Ciencias Naturales; 1928.

Marshall AD, Compagno LJV, Bennett MB. Redescription of the genus Manta with resurrection of Manta alfredi (Krefft, 1868) (Chondrichthyes; Myliobatoidei; Mobulidae). Zootaxa. 2009:2301.1-28. https://doi.org/10.3161/ $000345409 \times 484856$.

Müller J, Henle J. Systematische Beschreibung der Plagiostomen. Berlin: Verlag von Veit und Comp; 1841

Notarbartolo di Sciara G. A revisionary study of the genus Mobula Rafinesque, 1810 (Chondrichthyes, Mobulidae), with the description of a new species. Zool J Linnean Soc. 1987;91:1-91.

Notarbartolo di Sciara G. Natural history of the rays of the genus Mobula in the Gulf of California. Fish Bull. 1988;86(1):45-66.

Notarbartolo di Sciara G, Lauriano G, Pierantonio N, Cañadas A, Donovan G, Panigada S. The devil we don't know: investigating habitat and abundance of endangered giant devil rays in the North-western Mediterranean Sea. PloS One. 2015;10(11):e0141189. https://doi.org/10.1371/journal.pone.0141189.

Notarbartolo di Sciara G, Serena F. Term embryo of Mobula mobular (Bonnaterre, 1788) from the northern Tyrrhenian Sea. Atti della Società italiana di Scienze naturali e del Museo Civico di Storia naturale di Milano. 1988;129(4):396-400.

Paulin CD, Habib G, Carey CL, Swanson PM, Voss GJ. New records of Mobula japanica and Masturus lanceolatus, and further records of Luvaris imperialis from New Zealand. N Z J Mar Freshw Res. 1982;16:11-7.

Pellegrin J. Sur une raie cornue gigantesque pêchée à Oran. Bulletin du Muséum National d'Histoire Naturelle. 1901;7:327-8.

Poortvliet M, Olsen JL, Croll DA, Bernardi G, Newton K, Kollias S, O'Sullivan J, Fernando D, Stevens G, Galván Magaña F, Seret B, Wintner S, Hoarau G. A dated molecular phylogeny of manta and devil rays (Mobulidae) based on mitogenome and nuclear sequences. Mol Phylogenet Evol. 2015;83:72-85. https://doi.org/10.1016/j.ympev.2014.10.012

Rafrafi-Nouira S, El Kamel-Moutalibi O, Ben Amor MM, Capapé C. Additional records of spinetail devil ray Mobula japanica (Chondrichthyes: Mobulidae) from the Tunisian coast (Central Mediterranean). Annales. 2015;25(2):103-8.

Sakalli A, Yucel N, Capapé C. Confirmed occurrence in the Mediterranean Sea of Mobula japanica (Müller \& Henle, 1841) with a first record off the Turkish coasts. J Appl Ichthyol. 2016:1-3. https://doi.org/10.1111/jai.13218.

Scacco U, Consalvo I, Mostarda E. First documented catch of the giant devil ray Mobula mobular (Chondrichthyes: Mobulidae) in the Adriatic Sea. Mar Biodivers Rec. 2008;2:e93. https://doi.org/10.1017/S1755267209001110.

Sobral AF, Afonso P. Occurrence of mobulids in the Azores, Central North Atlantic. J Mar Biol Assoc UK. 2014;94(8):1-5. https://doi.org/10.1017/ S0025315414000964.

Stevens G, Fernando D, Dando M, Notarbartolo di Sciara G. Guide to the manta and devil rays of the world. Plymouth: Wild Nature Press; 2018.

Storai T, Zinzula L, Repetto S, Zuffa M, Morgan A, Mandelman J. Bycatch of large elasmobranchs in the traditional tuna traps (tonnare) of Sardinia from 1990 to 2009. Fish Res. 2011;109:74-9. https://doi.org/10.1016/j.fishres.2011.01.018.
Walbaum JJ. Petri Artedi sueci genera piscium. In: Ichthyologiae pars III, vol. 3. Greifswald: Ant Ferdin Rose Grypeswaldiae; 1792. p. 1-723.

White WT, Corrigan S, Yang L, Henderson AC, Bazinet AL, Swofford DL, Naylor GJP. Phylogeny of the manta and devilrays (Chondrichthyes: Mobulidae), with an updated taxonomic arrangement for the family. Zool J Linnean Soc. 2017;20:1-26. https://doi.org/10.1093/zoolinnean/zlx018.

Wiley EO, Lieberman BS. Phylogenetics: theory and practice of phylogenetic systematics. 2nd ed: Wiley-Blackwell; 2011. https://doi.org/10.1002/ 9781118017883.

\section{Publisher's Note}

Springer Nature remains neutral with regard to jurisdictional claims in published maps and institutional affiliations.
Ready to submit your research? Choose BMC and benefit from:

- fast, convenient online submission

- thorough peer review by experienced researchers in your field

- rapid publication on acceptance

- support for research data, including large and complex data types

- gold Open Access which fosters wider collaboration and increased citations

- maximum visibility for your research: over $100 \mathrm{M}$ website views per year

At $\mathrm{BMC}$, research is always in progress.

Learn more biomedcentral.com/submissions 